\title{
Cells per Millimeter Squared
}

National Cancer Institute

\section{Source}

National Cancer Institute. Cells per Millimeter Squared. NCI Thesaurus. Code C92614.

A cell based measurement for cell count per square millimeter area. 